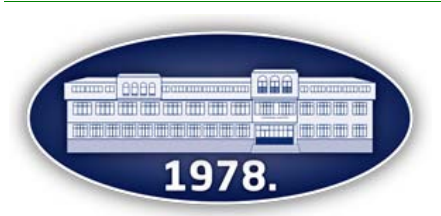

Publisher: Faculty of Agronomy Čačak

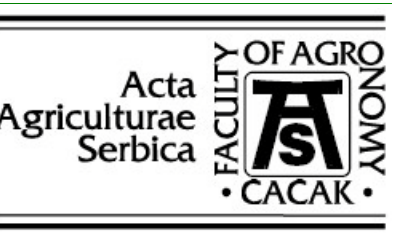

\title{
Irrigation scheduling strategies for pepper based on evaporation and reference evapotranspiration
}

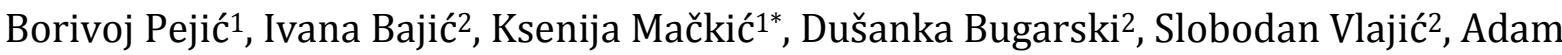 \\ Takač², Miroljub Aksić3 \\ ${ }^{1}$ University of Novi Sad, Faculty of Agriculture, Trg Dositeja Obradovića 8, 21102 Novi Sad, Republic of Serbia \\ ${ }^{2}$ Institute of Field and Vegetable Crops Novi Sad, Maksima Gorkog 30, 21101 Novi Sad, Republic of Serbia \\ ${ }^{3}$ University of Priština - Kosovska Mitrovica, Faculty of Agriculture, Kopaonička bb, 38228 Lešak, Republic of Serbia
}

*Corresponding author: ksenija@polj.uns.ac.rs

Received 23 October 2020; Accepted 11 June 2021

\begin{abstract}
A B S T R A C T
The experiment with drip irrigated pepper was conducted at the Rimski Šančevi experimental field of the Institute of Field and Vegetable Crops in Novi Sad in 2019. The irrigation was scheduled on the basis of the water balance method. Two methods were used to compute the daily evapotranspiration of pepper $\left(E_{\mathrm{d}}\right)$ : reference evapotranspiration $\left(\mathrm{ET}_{\mathrm{o}}\right)$ and evaporation from an open water surface $\left(\mathrm{E}_{\mathrm{o}}\right)$. Crop coefficients $\left(\mathrm{k}_{\mathrm{c}}\right)$ and corrective coefficients $(\mathrm{k})$ were used to convert $\mathrm{ET}_{\mathrm{o}}$ and $\mathrm{E}_{\mathrm{o}} \mathrm{Values}_{\mathrm{into}} \mathrm{ET}_{\mathrm{d}}$. $\mathrm{K}_{\mathrm{c}}$ and $\mathrm{k}$ were $0.3-0.4,0.6-0.7,0.9-1.1,0.8-0.9$ and $0.4,0.7,1.0$ and 0.8 for initial stage, crop development, mid season, and late season, respectively. ETo was calculated by the Hargreaves equation. $\mathrm{E}_{0}$ values were measured by a Class-A pan located at a meteorological station near the experimental plot. Irrigation started when readily available water (RAW) in the $0.3 \mathrm{~m}$ soil layer was completely absorbed by plants. Differences in crop yield (Y) and irrigation water use efficiency (IWUE) obtained using Eo $\left(42.58 \mathrm{t} \mathrm{ha}^{-1}, 15.20 \mathrm{~kg} \mathrm{~m}^{-3}\right)$ and ETo $\left(40.78 \mathrm{t} \mathrm{ha}^{-1}, 14.56 \mathrm{~kg} \mathrm{~m}^{-3}\right)$ were not statistically different. Evapotranspiration rate was 364.2 $\mathrm{mm}$ and $337.3 \mathrm{~mm}$ in $\mathrm{E}_{\mathrm{o}}$ and $\mathrm{ET}_{\mathrm{o}}$ variant, respectively. The fact that the differences in $\mathrm{Y}$ and IWUE between different calculations of $\mathrm{ET}_{\mathrm{d}}$ were not statistically significant indicates that both methods can be recommended for irrigation scheduling programs for pepper in the climatic conditions of the Vojvodina region. However, priority should be given to $\mathrm{ET}_{\mathrm{o}}$ due to the easy accessibility and reliability of data.
\end{abstract}

Keywords: pepper, irrigation, yield, water productivity, evapotranspiration.

\section{И 3 В $О$ Д}

Наводњавање паприке системом кап по кап обављено је у Институту за ратарство и повртарство на огледном пољу Римски Шанчеви (Нови Сад) 2019. године. Време заливања је одређивано водним билансом. Две методе су коришћене за обрачун дневног утрошка воде на евапотранспирацију паприке (ET $)_{d}$ : референтна евапотранспирација (ЕТ $)$ и евапорација са слободне водене површине $\left(\mathrm{E}_{\mathrm{o}}\right)$. Коефицијенти културе $\left(\mathrm{k}_{\mathrm{c}}\right)$ и коефицијенти корекције $(\mathrm{k})$ коришћени су

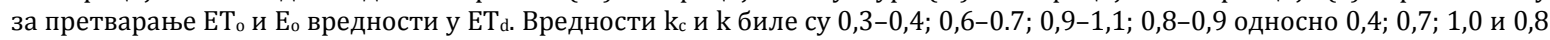
за почетак вегетације, интензивни пораст, централни део вегетације и крај вегетације. ЕТ је рачуната поступком Харгривса (Hargreaves). Ео вредности су мерене евапориметром класе А, постављеним на метеоролошкој станици у непосредној близини огледне парцеле. Наводњавање је обављано када је лакоприступачна вода у слоју земљишта до 30 $\mathrm{cm}$ била утрошена од стране биљака. Разлике у приносу (Y) и продуктивности утрошене воде наводњавањем (IWUE) коришћењем $\mathrm{E}_{o}\left(42,58 \mathrm{t} \mathrm{ha}^{-1}, 15,20 \mathrm{~kg} \mathrm{~m}^{-3}\right)$ и $\mathrm{ET}_{0}\left(40,78 \mathrm{t} \mathrm{ha}^{-1}, 14,56 \mathrm{~kg} \mathrm{~m}^{-3}\right)$ нису биле статистички значајне. Вредности евапотранспирације у периоду вегетације паприке биле су 364,2 mm односно 337,3 mm на варијантама обрачуна Е и ЕТ . Чињеница да нису утврђене статистички значајне разлике у вредностима Y и IWUE указује да се обе методе могу користити у обрачуну $\mathrm{ET}_{\mathrm{d}}$ у реализацији рационалног заливног режима паприке у климатским условима Војводине. Међутим, предност због доступности података ипак треба дати поступку $\mathrm{ET}_{\text {o. }}$

Кључне речи: паприка, наводњавање, принос, продуктивност утрошене воде, евапотранспирација.

\section{Introduction}

Pepper (Capsicum annum L.) belongs to the family Solanaceae. It is cultivated in warm climate regions worldwide, such as Asia, northern America, southern and central Europe, and tropical and subtropical Africa (Thampi, 2004), and is native to Mexico, Central America, and northern South America (Echer et al., 2002). It is the world's second most important vegetable after tomato. The world production of fresh pepper is about 34.5 million tons (MT) and 3.9 MT of dry pepper (FAOSTAT, 2016); 1.93 million ha of cropgrowing surface area (Ertek and Bolat, 2016) yielded an average of $12 \mathrm{t} \mathrm{ha}^{-1}$ (FAOSTAT, 2016). China (17.5 MT), Mexico (2.7 MT), Indonesia (2.0 MT), and Spain (1.1MT) we re the largest producers of fresh pepper, while India (1.4MT) was the highest producer of dry peppers. Pepper is one of the leading 
horticultural crops in Serbia. Over the last three years (2017/2019), a total of 15460 hectares of land were under pepper, with an average yield of $12 \mathrm{t} \mathrm{ha}^{-1}$ and an annual production of $187000 \mathrm{t}$ (Statistical Office of the Republic of Serbia, 2019). In Vojvodina, the northern province of the Republic of Serbia, pepper is grown on 2900 hectares, with an average yield of $15.9 \mathrm{t} \mathrm{ha}^{-1}$ and an annual production of $43000 \mathrm{t}$. Lower average pepper yields in Serbia, compared to those achieved in the leading pepper growing countries (South Korea $67.2 \mathrm{t} \mathrm{ha}^{-1}$, USA $53.9 \mathrm{t} \mathrm{ha}^{-1}$, Japan $53.9 \mathrm{t} \mathrm{ha}^{-1}$, and Germany $45.6 \mathrm{t} \mathrm{ha}^{-1}$, FAOSTAT, 2016), are primarily due to improper management practices, insufficient amount and unfavorable distribution of precipitation in the growing season, and poor optimization of the irrigation regime.

Pepper is considered one of the most susceptible crops with regard to water stress in horticulture (Antony and Singandhupe, 2004; Showemimo and Olarewaju, 2007; Ferrara et al., 2011). Many studies confirmed that reductions in the water supply at any growth stage of pepper have a negative effect on yield. For high yields of good quality pepper, an adequate water supply is required during the whole crop cycle (Dorji et al., 2005; Sezen et al., 2006).

Thus, irrigation scheduling is one of the main elements of irrigation practice (Vučić, 1976; Bošnjak, 1983; Pejić, 1993), and the most effective tool for increasing the yield of cultivated plants and water use efficiency as well saving water by avoiding its excessive application. The aim of irrigation is to optimize the soil water content, so that plant water deficit is controlled and the root is not water-logged. Inappropriate irrigation could result in water stress (Pejić etal, 2011a,b).

One of the most important aspects of irrigation practice to be considered is the determination of the irrigation schedule for different cultivated plants in relation to the soil, climatic conditions and biological properties of plants. There are several methods used for determining the time of irrigation, the most common being the water budget method, which is a quick and convenient means of estimating when to apply irrigation. The budget method estimates water depletion from the root zone due to evapotranspiration, with irrigation and effective rainfall as inputs. The amount of water lost through surface runoff and deep percolation (moving below the root zone) must be taken into consideration. To schedule irrigation using the water budget method, precise estimation of daily crop evapotranspiration is required (Pejić, 2000; Ertek et al., 2007; Bryla et al., 2010; Pejić et al., 2019). Experimentally, evapotranspiration can be measured directly in the field on experimental plots or by lysimeters. This, however, is both difficult and expensive. Therefore, crop evapotranspiration $\left(E T_{c}\right)$ estimation based on reference evapotranspiration (ETo) and crop coefficients $\left(\mathrm{k}_{\mathrm{c}}\right)$ will increasingly gain ground in irrigation scheduling over the coming years. Numerous papers have shown that the Penman-Monteith method, the FAO-56 PM equation (Allen et al., 1998), is reliable in all climatic conditions and is therefore proposed by the FAO organization as standard for reference evapotranspiration $\left(\mathrm{ET}_{\mathrm{o}}\right)$ calculation. Due to its simplicity and high correlation with the results obtained by the Penman-Monteith method, the Meteorological Institute of Serbia gives daily values of $\mathrm{ET}_{\mathrm{o}}$ calculated by the Hargreaves method. The relationship between $\mathrm{ET}_{\mathrm{o}}$ and the crop actually grown is given by the crop factor $\left(\mathrm{k}_{\mathrm{c}}\right)$. ETc can be more simply calculated from pan evaporation ( $\left.E_{0}\right)$ and crop factor (k). Studies have revealed that the pan evaporation method gives better results than the other methods for $\mathrm{ET}_{\mathrm{c}}$ estimation. This is due to the identical effects of air temperature, solar radiation and other climatic factors on both $\mathrm{E}_{\mathrm{o}}$ and $\mathrm{ET}_{\mathrm{c}}$ (Smajstrla et al., 2000). To clarify the relationship between $E_{o}$ and $E_{c}$, regression analysis should be applied to determine the crop factor (k) (Vučić, 1976; Bošnjak, 1983; Ertek and Bolat, 2016). Class-A pan is the most common type of evaporation pan, provided it is used uniformly. Today, this evaporimeter is used at meteorological stations around the world, primarily due to the simplicity of measurement techniques, low cost and easy maintenance (Sahin et al., 2015).

In the situation of growing human population, increasing food demand and limited fresh water resources, water use efficiency in irrigated agriculture is of particular importance. Irrigation water use efficiency (IWUE) provides a more realistic assessment of irrigation effectiveness. It is a useful indicator for quantifying the impact of irrigation scheduling decisions and irrigation water applied on crop yield. IWUE values will be below the optimum if the irrigation schedule is not synchronized with the water needs of crops, soil properties and weather conditions (Pejić et al., 2018). The parameter, IWUE, generally tends to increase with a decline in irrigation if that water deficit does not occur at any single growth period (Howell, 2001). All the factors that increase yield and decrease water consumption through ET favorably affect the water use efficiency (Wang et al., 1996).

For the proper design of irrigation systems or the development of an irrigation schedule for any crop, data on crop requirements for water $\left(\mathrm{ET}_{\mathrm{c}}\right)$ are needed (Sahin et al., 2015; Pejić et al., 2016). Water requirements for pepper during the growing season are much higher than those for other crops, which is the result of the poorly developed root system (Ertek and Bolat, 2016) and large transpiring leaf surface (Delfine et al., 2000). For high pepper yields, an adequate water supply and relatively moist soils are required during the total growing period (Bošnjak et al., 2005; Tanaskovik et al., 2016). The water requirement of pepper in the climatic conditions of Vojvodina is 571667 mm (Bošnjak et al., 2005).

The objective of the study was to compare $\mathrm{ET}_{0}$ and $E_{o}$ commonly used for irrigation programs and $\mathrm{ET}_{\mathrm{c}}$ prediction in order to determine which method is best suited to pepper growers in the climatic conditions of the Vojvodina region. The assessment will be made based on the yield and other growth parameters.

\section{Materials and methods}

The experiment with irrigated pepper was conducted in 2019 at the Rimski Šančevi experimental field of the Institute of Field and Vegetable Crops in Novi Sad, Serbia (N $45^{\circ} 20^{`}$ Lat., E $19^{\circ} 51^{`}$ Long., $84 \mathrm{~m}$ above sea level) on a calcareous chernozem soil on a loess terrace (Water physical properties - FC - soil water at field capacity, $26.01 \%$ of dry soil weight; LCM - soil water at lentocapillary moisture (625 kPa), 15.61 $\%$ of dry soil weight; WP - soil water at wilting point (1500 kPa), $12.65 \%$ of dry soil weight, SBD - soil bulk density, $1.13 \mathrm{~g} \mathrm{~cm}^{-3}$, D - rooting depth where bulk roots 
are expected to develop, $0.3 \mathrm{~m}$, RAW - readily available water not limiting for evapotranspiration, $40.56 \mathrm{~mm}$, Chemical characteristics - Reaction ( $\mathrm{pH}$ in water) 8.05; $\mathrm{CaCO}_{3}$ 1.95\%; Organic matter 2.63; N\% 0.173; Available $\mathrm{P}_{2} \mathrm{O}_{5} 23.2$ mg $100 \mathrm{~g}^{-1}$ soil; Available $\mathrm{K}_{2} \mathrm{O} 27.5$ mg $100 \mathrm{~g}^{-1}$ soil; Particle size - Total sand, silt and clay, 33\%, 48\% and $18 \%$, respectively; Texture grade - loam). In the period 1964-2018, the annual mean air temperature, precipitation and relative humidity were $11.6^{\circ} \mathrm{C}, 637$ $\mathrm{mm}$, and $75 \%$, respectively. According to the Hargreaves climate classification system, the study area is classified as semiarid in the summer period, from June to August (Bošnjak, 2001). Pepper variety 'Amfora' was used for the trials. The row and intra-row spacing was 0.7 and $0.25 \mathrm{~m}$, respectively. The size of the experiment plot was $67 \mathrm{~m}^{2}$, but the size of the experimental unit was $8.4 \mathrm{~m}^{2}(1.4 \times 6 \mathrm{~m})$ and was replicated four times.

The trial was established as a block design and adapted to the technical specifications of the drip irrigation system. The plants were irrigated with a lateral placed in every row with drippers spaced every $0.33 \mathrm{~m}$. Drippers had an average flow of $2.0 \mathrm{~L} \mathrm{hour}^{-1}$ under a pressure of $70 \mathrm{kPa}$. The irrigation was scheduled on the basis of the water balance method (the soil water budget). The budget method estimates water depletion from the root zone due to evapotranspiration, with an allowance being made for any water inputs (irrigation and effective rainfall). Irrigation started when readily available water in the $0.3 \mathrm{~m}$ soil layer was completely absorbed by plants. (Ertek and Bolat, 2016 reported that about 70\% of pepper roots are spreading at $10-30 \mathrm{~cm}$ soil depth, which indicates that deeper soil layers are not necessary for the cultivation of pepper.)

Two methods were used to compute the daily evapotranspiration of pepper $\left(\mathrm{ET}_{\mathrm{d}}\right)$ : reference evapotranspiration $\left(\mathrm{ET}_{0}\right)$ and evaporation from an open water surface $\left(E_{0}\right)$. Crop coefficients $\left(k_{c}\right)$ and crop factor $(\mathrm{k})$ were used to convert $\mathrm{ET}_{\mathrm{o}}$ and $\mathrm{E}_{\mathrm{o}}$ values into $\mathrm{ET}_{\mathrm{d}} . \mathrm{K}_{\mathrm{c}}$ and $\mathrm{k}$ were $0.3-0.4,0.6-0.7,0.9-1.1,0.8-0.9$ and $0.4,0.7,1.0$ and 0.8 for initial stage, crop development, mid season, and late season, respectively. $K_{c}$ and $k$ were considered for different growth stages of pepper based on FAO-56 (Allen et al., 1998). ETo was calculated by the Hargreaves equation (Hargreaves and Samani, 1985):

$$
\mathrm{ET}_{\mathrm{o}}=0.0023\left(\mathrm{~T}_{\mathrm{m}}+17.8\right) \sqrt{\mathrm{T}_{\max }-\mathrm{T}_{\min }} \mathrm{R}_{\mathrm{a}}
$$

where: $\mathrm{ET}_{0}$ - reference evapotranspiration (mm day $\left.^{-1}\right), \mathrm{T}_{\mathrm{m}}$-average daily air temperature $\left({ }^{\circ} \mathrm{C}\right), \mathrm{T}_{\max }-$ maximum daily temperature $\left({ }^{\circ} \mathrm{C}\right), \mathrm{T}_{\min }$-minimum daily temperature $\left({ }^{\circ} \mathrm{C}\right), \mathrm{R}_{\mathrm{a}}$-extraterrestrial radiation $\left(\mathrm{MJ} \mathrm{m}^{-2}\right.$ day $^{-1}$ ).

Daily $\mathrm{ET}_{\mathrm{o}}$ values were obained from the website of the Republic Hydrometeorological Service of Serbia (2020). E $E_{o}$ values were measured by a Class-A pan located at a meteorological station near the experimental plot.

Irrigation water use efficiency (IWUE) was calculated as fresh pepper yield $(\mathrm{Y})$ divided by the total seasonal irrigation water applied (I) (Tanner and Sinclair, 1983, Bos, 1985, Stanhill, 1986, Molden et al., 2010).

The irrigation rate was $20 \mathrm{~mm}$ at the beginning of the season and $30 \mathrm{~mm}$ in mid-season. The volume of irrigation water and the pressure in the system were controlled respectively by a flow meter and a pressure gauge installed in the hose nozzle used for irrigation.

Pepper seedlings were transplanted to treatment plots on June 18 and harvested by hand on September 20 at harvest maturity. Due to bad weather conditions, transplanting was done a month later. All recommended agronomic practices regarding the cultivation and plant protection of pepper were applied at the experimental plot.

The data reported for yield and yield components were subjected to analyses of variance (ANOVA). LSD test was used to group the means of irrigation when the F-test was significant. Different letters indicate significant differences between values.

\section{Results and discussion}

In the period July-August, rainfall was $83.5 \mathrm{~mm}$, which was lower by 41.5 than the long-term average for the region $(125 \mathrm{~mm})$, while the amount of water added by irrigation was $260 \mathrm{~mm}$ in both variants (Table 1, Figures 1 and 2). However, the average air temperature (Table 1$)$ in the same period $\left(22.6^{\circ} \mathrm{C}\right)$ was higher by $1.0^{\circ} \mathrm{C}$ compared to the long-term average $\left(21.6^{\circ} \mathrm{C}\right)$, which certainly affected the water consumed through evapotranspiration. Total $\mathrm{E}_{\mathrm{o}}$ and $\mathrm{ET}_{0}$ during the growing period of pepper were $539.3 \mathrm{~mm}$ and $453.8 \mathrm{~mm}$, respectively (Table 3 ).

The yield of pepper was $40.78 \mathrm{t} \mathrm{ha}^{-1}$ in the $\mathrm{ET}_{\text {o }}$ variant, and $42.58 \mathrm{t} \mathrm{ha}^{-1}$ in the $\mathrm{E}_{\mathrm{o}}$ variant (Table 2). The yields in tested variants were not statistically different. The result of the study is in line with the findings by Bošnjak et al. (2005), who reported that the yield of pepper cultivar 'Amfora' irrigated by sprinklers varied from 35.5 to $43.54 \mathrm{t} \mathrm{ha}^{-1}$, at the same experimental field. Trivikrama et al. (2018) reported similar results for pepper yield, in arid conditions of India, with different irrigation levels $0.5,0.75$, and $1.0 \mathrm{ET}_{\mathrm{c}}$; maximum yield of $(\mathbb{B}) 59 \mathrm{t}^{\mathrm{h}} \mathrm{h}^{-1}$ was obtained from treatment $1.0 \mathrm{ET}_{\mathrm{c}}$, with the seasonal irrigation water amount of $562.5 \mathrm{~mm}$. Also, Sezen et al. (2006) found the highest yield of drip irrigated pepper in the variant with full irrigation of 44.2-47.8 $\mathrm{t} \mathrm{ha}^{-1}$ under the Mediterranean climatic conditions of Turkey. Differences regarding yield components (number of fruits per plant, fruit weight) and morphological characteristics of pepper (fruit length, fruit diameter, pericarp thickness) between the two methods of $\mathrm{ET}_{\mathrm{d}}$ calculation were not significant, except for the content of dry matter; $7.4 \% \mathrm{E}_{\mathrm{o}}, 6.7 \% \mathrm{ET}_{\mathrm{o}}$ (Table 2). 
Table 1.

Sum of monthly precipitation (mm) and mean monthly air temperature for the growing season of pepper (Meteorological Station, Rimski Šančevi) in 2019

\begin{tabular}{|c|c|c|c|c|}
\hline Month & Precipitation & Temperature & $\begin{array}{c}\text { Long term average } \\
\text { precipitation } \\
(1964-2018)\end{array}$ & $\begin{array}{c}\text { Long term average air } \\
\text { temperature } \\
(1964-2018)\end{array}$ \\
\hline June & $20^{+}$ & $23.3^{\dagger}$ & $89^{\dagger}$ & $20.1^{\dagger}$ \\
\hline July & 18 & 22.0 & 67 & 21.8 \\
\hline August & 65 & 23.1 & 58 & 21.4 \\
\hline September & $16^{\dagger}$ & $19.2^{\dagger}$ & $48^{\dagger}$ & $17.0^{\dagger}$ \\
\hline Total/average & $\begin{array}{c}120 \\
(83.5)^{\ddagger}\end{array}$ & $\begin{array}{c}21.9 \\
(22.6)^{\ddagger}\end{array}$ & $\begin{array}{c}262 \\
(125)^{\ddagger}\end{array}$ & $\begin{array}{c}20.1 \\
(21.6)^{\ddagger}\end{array}$ \\
\hline
\end{tabular}
average values, the data for the period July-August are relevant.

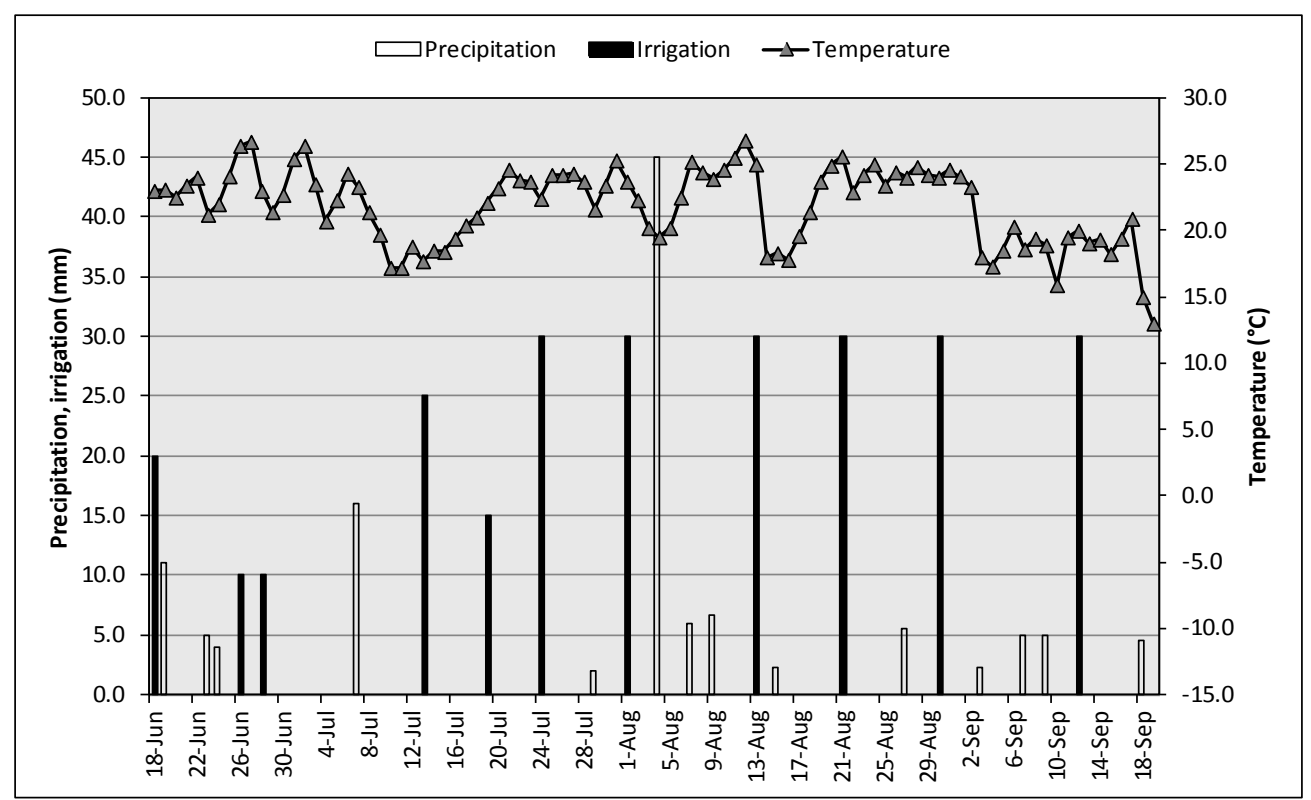

Figure 1. Irrigation schedules, irrigation water applied, and meteorological data (daily precipitation and mean daily air temperatures) in $\mathrm{ET}_{0}$ variant

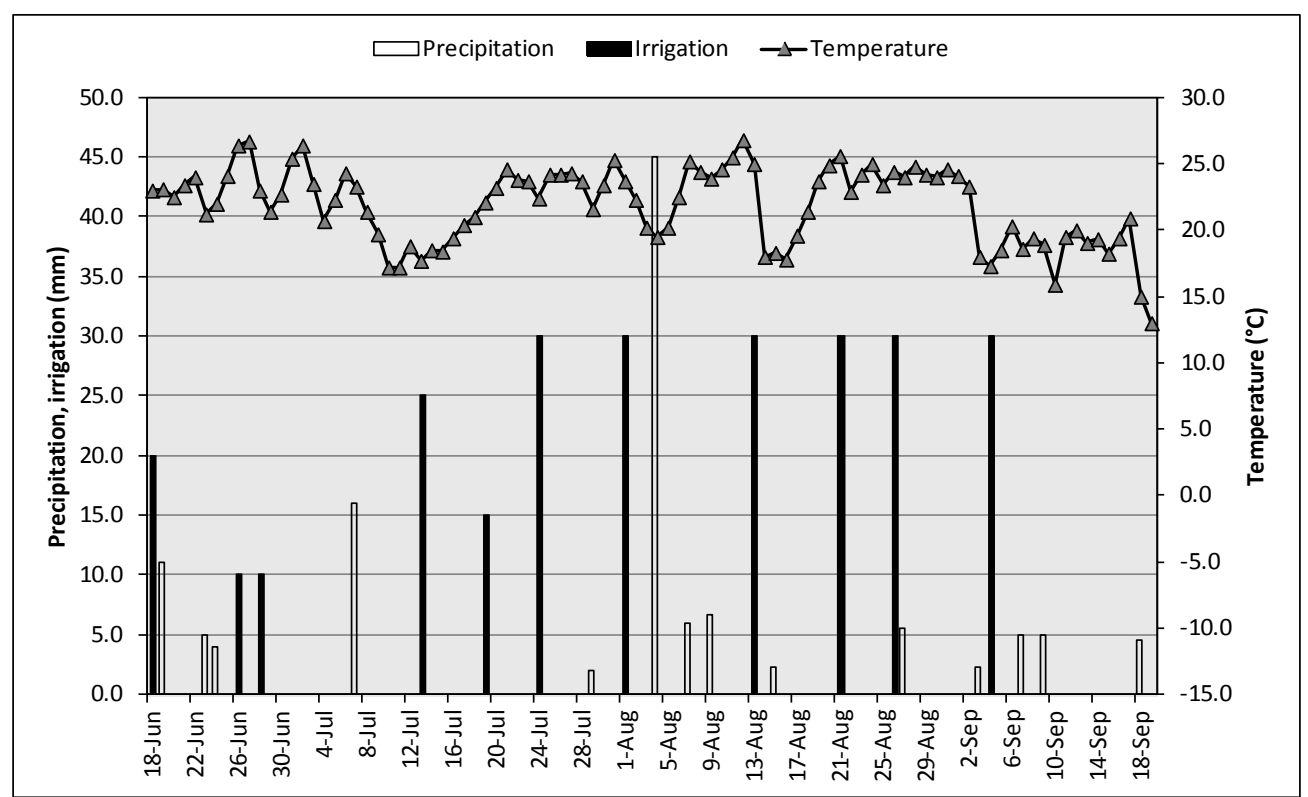

Figure 2. Irrigation schedules, irrigation water applied, and meteorological data (daily precipitation and mean daily air temperatures) in $\mathrm{E}_{\mathrm{o}}$ variant

Efficient use of irrigation water (IWUE) is essential for increasing agricultural productivity. Pejic et al. (2011a) pointed out that special attention should be paid when comparing results because IWUE calculations may be different (Viets, 1962, Tanner and Sinclair, 1983, Bos, 1985, Stanhill, 1986, Molden et al., 2010). In rainfed areas under complementary irrigation, IWUE calculation differs (the calculation also takes into 
account yields without irrigation, Bos, 1985) in relation to arid regions where crop production cannot be realized under natural water supply conditions (IWUE values are calculated as the ratio of yield to water added by irrigation, Viets, 1962). IWUE values were $15.2 \mathrm{~kg} \mathrm{~m}^{-3}$ in $\mathrm{E}_{\mathrm{o}}$ and $14.6 \mathrm{~kg} \mathrm{~m}^{-3}$ in $\mathrm{ET}_{\mathrm{o}}$ variant. Padrón et al. (2015) reported the IWUE value of $12.3 \mathrm{~kg} \mathrm{~m}^{-3}$ for pepper in subtropical humid climatic conditions in Brasil for the yield of $37.1 \mathrm{t} \mathrm{ha}^{-1}$ and the amount of irrigation water applied of $301 \mathrm{~mm}$. IWUE of $4.2 \mathrm{~kg} \mathrm{~m}^{-3}$ for the yield of $21.57 \mathrm{t} \mathrm{ha}^{-1}$ and irrigation rate of 518 mm was found in Turkey (Kara and Yildirim, 2015). It is very interesting to compare our results with the results of drip irrigated pepper cultivated in the arid region of Northwest China regarding yield, crop evapotranspiration and water use efficiency. In the growing season from May to September the highest IWUE value of $19.27 \mathrm{~kg} \mathrm{~m}^{-3}$ coincided with the yield of $34.5 \mathrm{t} \mathrm{ha}^{-1}$. The soil matric potential of $-30 \mathrm{kPa}$ at $25 \mathrm{~cm}$ depth was recommended for irrigation management. Water applied by irrigation and water consumed through evapotranspiration were $179 \mathrm{~mm}$ and 313.1 $\mathrm{mm}$, respectively (Liu et al., 2012).

Table 2.

Yield and yield components of pepper depending on the method used for computing the daily amount of water consumed through evapotranspiration

\begin{tabular}{|c|c|c|c|c|c|c|c|c|c|}
\hline Var. & Rep. & $\begin{array}{l}\text { No. of } \\
\text { fruits } \\
\text { per } \\
\text { plant }\end{array}$ & $\begin{array}{c}\text { Fruit } \\
\text { weight } \\
\text { (g) }\end{array}$ & $\begin{array}{c}\text { Fruit } \\
\text { length } \\
(\mathrm{cm})\end{array}$ & $\begin{array}{c}\text { Fruit } \\
\text { diameter } \\
(\mathrm{cm})\end{array}$ & $\begin{array}{c}\text { Pericarp } \\
\text { thickness } \\
(\mathrm{mm})\end{array}$ & $\begin{array}{c}\text { Content of } \\
\text { dry } \\
\text { matter } \\
(\%)\end{array}$ & $\begin{array}{l}\text { Yield } \\
\left(\mathrm{t} \mathrm{ha}^{-1}\right)\end{array}$ & $\begin{array}{c}\text { IWUE } \\
\left(\mathrm{kg} \mathrm{m}^{-3}\right)\end{array}$ \\
\hline \multirow{4}{*}{$\mathrm{E}_{o}$} & 1 & 9 & 87.6 & 13 & 5.6 & 4 & 8.0 & 44.31 & 15.82 \\
\hline & 2 & 9 & 92.3 & 13 & 5.8 & 5 & 6.9 & 44.59 & 15.92 \\
\hline & 3 & 8 & 97.8 & 12 & 5.9 & 4 & 7.3 & 44.64 & 15.94 \\
\hline & 4 & 7 & 90.1 & 13 & 5.7 & 4 & 7.2 & 36.80 & 13.14 \\
\hline \multicolumn{2}{|c|}{ average } & $8 \mathrm{a}$ & $92.0 \mathrm{a}$ & $12.8 \mathrm{a}$ & $5.8 \mathrm{a}$ & $4.2 \mathrm{a}$ & $7.4 \mathrm{a}$ & $42.58 \mathrm{a}$ & $15.20 \mathrm{a}$ \\
\hline \multirow{4}{*}{$\mathrm{ET}_{\mathrm{o}}$} & 1 & 8 & 96.3 & 13 & 5.8 & 4 & 6.6 & 42.21 & 15.08 \\
\hline & 2 & 7 & 92.8 & 12 & 5.8 & 4 & 6.5 & 37.56 & 13.41 \\
\hline & 3 & 9 & 84.6 & 13 & 6.5 & 4 & 7.0 & 41.49 & 14.82 \\
\hline & 4 & 9 & 81.6 & 12 & 5.5 & 4 & 6.5 & 41.88 & 14.96 \\
\hline \multicolumn{2}{|c|}{ average } & $8 a$ & $88.8 \mathrm{a}$ & $12.5 \mathrm{a}$ & $5.9 \mathrm{a}$ & $4.0 \mathrm{a}$ & $6.7 b$ & $40.78 \mathrm{a}$ & $14.56 \mathrm{a}$ \\
\hline
\end{tabular}

$\mathrm{E}_{0}$ - evaporation from an open water surface, $\mathrm{ET}_{\mathrm{o}}$ - reference evapotranspiration

Values followed by the same letter are not significantly different at the 0.05 probability level

Evapotranspiration rates were $364.2 \mathrm{~mm}$ and $337.3 \mathrm{~mm}$ in $\mathrm{E}_{\mathrm{o}}$ and $\mathrm{ET}_{\mathrm{o}}$ variants, respectively (Tables 3,4 , and 5). The obtained values are lower than those previously reported by Bošnjak et al. (2005) for the climatic conditions of Vojvodina (571-667 mm), primarily due to the shorter growing period. Similar $\mathrm{ET}_{\mathrm{c}}$ values $(380 \mathrm{~mm})$ for humid Indian climate were found by Arya et al. (2017). Sezen et al. (2011) reported the yields of $21.390 \mathrm{tha}^{-1}$ and $35.92 \mathrm{t} \mathrm{ha}^{-1}$ and seasonal evapotranspiration of $327 \mathrm{~mm}$ and $517 \mathrm{~mm}$ of pepper in water-stressed and well irrigated treatments, respectively, under the Mediterranean climatic conditions of Turkey. Comparing the values of water consumed through evapotranspiration for cultivated plants is an ungrateful task. Evapotranspiration depends on the amount of water in the soil (Vučić, 1976), environmental conditions (Bošnjak, 1983), the length of the growing period (Pejić et al., 2007). Evapotranspiration is greatest at optimal soil moisture; it decreases with decreasing water content in the soil. The obtained monthly (July and August) and daily values of pepper ET (Tables 3, 4, 5 and Figure 3) in the range 108-194 $\mathrm{mm}$ and 3.5-6.3, respectively, are in agreement with Bošnjak et al. (2005). They reported pepper ET in July and August in the range from 161 to $181 \mathrm{~mm}$ and average daily values of $5.5 \mathrm{~mm}$. ET $_{\mathrm{d}}$ values ranged from less than $2 \mathrm{~mm}^{-1 a y}{ }^{-1}$ early in the season, when plants were small, to $8-9 \mathrm{~mm}^{-1 a y}{ }^{-1}$ during the peak ET period in late July to early August (Figure 3), when plants reached full effective cover and peppers were ready for harvest; these values were completely in agreement with the results obtained by weighing lysimeters in the central Californian region, as reported by Bryla et al. (2010). Pepper consumed the highest amount of water during fruit setting and fruit growth, from mid-season to late season $(130.4 \mathrm{~mm}$ and 159.9 $\mathrm{mm}$ for $\mathrm{ET}_{\mathrm{o}}$ and $\mathrm{E}_{\mathrm{o}}$ variants, respectively) (Table 3). Therefore, this growth stage of pepper is most sensitive to water stress. But, many studies confirmed that obtaining high yields of pepper requires an adequate water supply during the whole crop cycle (Sezen et al., 2006, Demirel et al., 2012). 


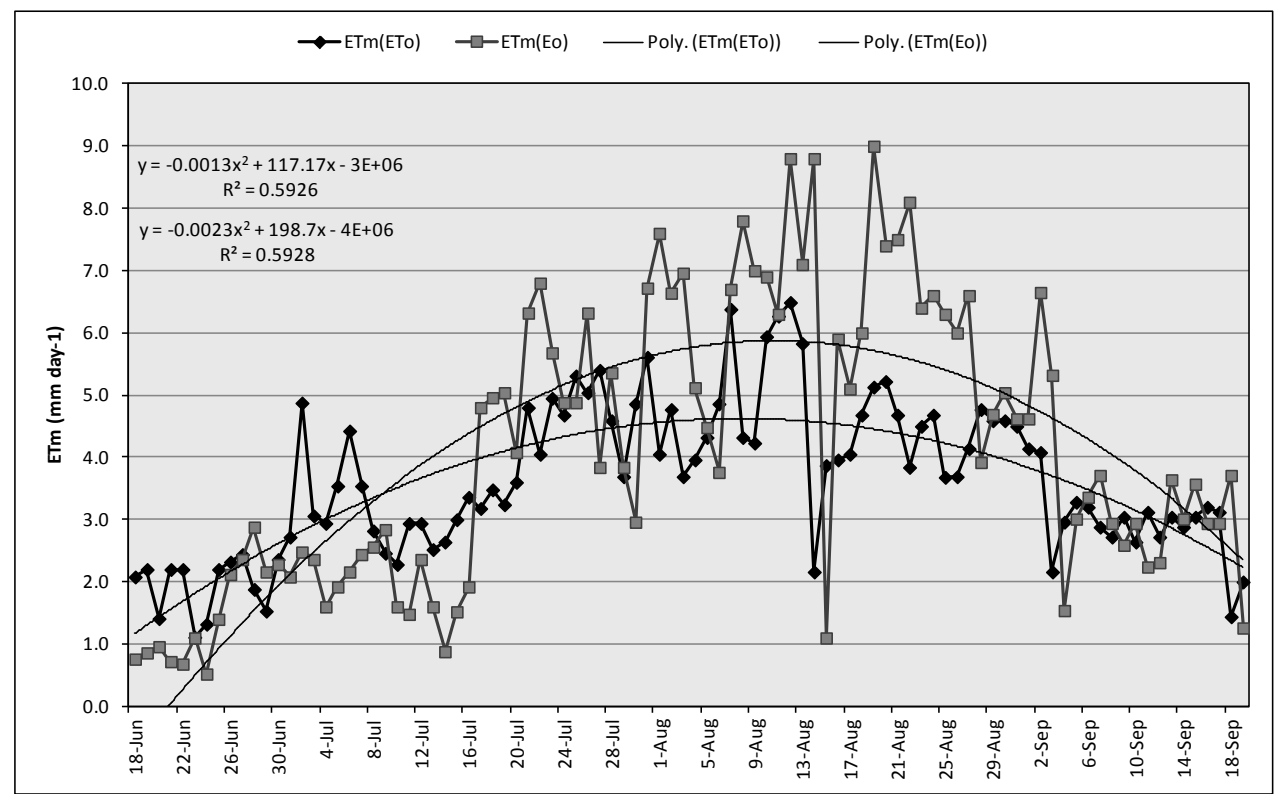

Figure 3. Daily pepper evapotranspiration $\left(\mathrm{ET}_{\mathrm{d}}\right)$

Table 3.

Reference evapotranspiration $\left(\mathrm{ET}_{\mathrm{o}}\right)$, evaporation $\left(\mathrm{E}_{\mathrm{o}}\right)$, and pepper evapotranspiration $\left(\mathrm{ET}_{\mathrm{m}}, \mathrm{ET}_{\mathrm{d}}\right)$

\begin{tabular}{ccccccc}
\hline Growth stages & $\mathrm{ET}_{\mathrm{o}}(\mathrm{mm})$ & $\mathrm{ET}_{\mathrm{c}}(\mathrm{mm})$ & $\mathrm{ET}_{\mathrm{d}}(\mathrm{mm})$ & $\mathrm{E}_{\mathrm{o}}(\mathrm{mm})$ & $\mathrm{ET}_{\mathrm{c}}(\mathrm{mm})$ & $\mathrm{ET}_{\mathrm{d}}(\mathrm{mm})$ \\
\hline $\begin{array}{c}\text { Initial stage } \\
\text { June 18 - July 1 }\end{array}$ & 74.4 & 28.0 & 2.0 & 66.2 & 20.9 & 1.5 \\
$\begin{array}{c}\text { Crop development } \\
\text { July 2 - July 22 } \\
\quad \text { Mid-season }\end{array}$ & 110.1 & 69.7 & 2.2 & 114.3 & 61.7 & 2.0 \\
$\quad \begin{array}{c}\text { July 23 - August 13 } \\
\quad \text { Late season }\end{array}$ & 114.0 & 109.2 & 5.0 & 149.4 & 121.7 & 5.5 \\
$\begin{array}{c}\text { August 14 - September 20 } \\
\text { Sum /average for growing }\end{array}$ & 157.9 & 130.4 & 4.7 & 209.4 & 159.9 & 5.7 \\
$\quad$ season & 456.4 & 337.3 & 3.5 & 539.3 & 364.2 & 3.7 \\
\hline
\end{tabular}

Table 4.

Water balance for pepper in $\mathrm{ET}_{\mathrm{o}}$ variant

\begin{tabular}{cccccc}
\hline \multirow{2}{*}{$\begin{array}{c}\text { Balance } \\
\text { elements }\end{array}$} & June & July & August & September & Growing season \\
\cline { 2 - 5 } ET $_{\mathrm{o}}$ & 68 & 165 & 152 & 72 & 457 \\
$\mathrm{k}_{\mathrm{c}}$ & $0.3-0.4$ & $0.6-0.7$ & $0.9-1.1$ & $0.8-0.9$ & - \\
$\mathrm{t}$ & 23.3 & 22.0 & 23.1 & 18.9 & 21.8 \\
$\mathrm{ET}_{\mathrm{m}}$ & 25 & 116 & 142 & 54 & 337 \\
$\mathrm{P}$ & 20 & 18 & 66 & 17 & 121 \\
$\Delta$ & -5 & -25 & 0 & 0 & - \\
$\mathrm{r}$ & 30 & 25 & 0 & 0 & 151 \\
$\mathrm{ET}_{\mathrm{a}}$ & 25 & 43 & 66 & 17 & 186 \\
$\mathrm{~d}$ & 0 & 73 & 76 & 37 & 0 \\
$\mathrm{~s}$ & 0 & 0 & 0 & 0 & 260 \\
$\mathrm{Irr}$ & $40^{*}$ & 70 & 120 & 30 & 3.3 \\
$\mathrm{ET}$ & 1.9 & 3.7 & 4.6 & 3.0 &
\end{tabular}

$\mathrm{ET}_{\mathrm{o}}$ - reference evapotranspiration $(\mathrm{mm}), \mathrm{k}_{\mathrm{c}}$ - crop coefficients, $\mathrm{t}-$ mean monthly air temperature $\left({ }^{\circ} \mathrm{C}\right), \mathrm{ET}_{\mathrm{c}}-$ plant evapotranspiration under irrigation conditions $(\mathrm{mm}), \mathrm{P}$ - the monthly amount of precipitation $(\mathrm{mm}), \Delta-$ the difference between ET and $\mathrm{P}(\mathrm{mm}), \mathrm{r}$ - pre-season readily available soil water reserve $(\mathrm{mm}), \mathrm{ET}_{\mathrm{a}}$ - plant evapotranspiration under non-irrigated conditions $(\mathrm{mm}), \mathrm{d}$ - the deficit of readily available water in the soil $(\mathrm{mm}), \mathrm{s}-$ surplus water, i.e. water percolated into the soil layers below the active rhizosphere of plants (mm), Irr - water applied by irrigation ( $\mathrm{mm}$ ) 
Table 5.

Water balance for pepper in Eovariant

\begin{tabular}{|c|c|c|c|c|c|}
\hline \multirow{2}{*}{$\begin{array}{l}\text { Balance } \\
\text { elements }\end{array}$} & \multicolumn{5}{|c|}{ Month } \\
\hline & June & July & August & September & Growing season \\
\hline $\mathrm{E}_{\mathrm{o}}$ & 61 & 175 & 211 & 92 & 539 \\
\hline $\mathrm{k}$ & 0.4 & 0.7 & 1.0 & 0.8 & - \\
\hline $\mathrm{t}$ & 23.3 & 22.0 & 23.1 & 18.9 & 21.8 \\
\hline $\mathrm{ET}_{\mathrm{c}}$ & 19 & 108 & 194 & 43 & 364 \\
\hline $\mathrm{P}$ & 20 & 18 & 66 & 17 & 121 \\
\hline$\Delta$ & +1 & -30 & 0 & 0 & - \\
\hline $\mathrm{r}$ & 30 & 30 & 0 & 0 & - \\
\hline $\mathrm{ET}_{\mathrm{a}}$ & 19 & 48 & 66 & 17 & 150 \\
\hline $\mathrm{d}$ & 0 & 60 & 128 & 26 & 214 \\
\hline $\mathrm{s}$ & 1 & 0 & 0 & 0 & 0 \\
\hline Irr & $40^{*}$ & 70 & 120 & 30 & 260 \\
\hline $\mathrm{ET}_{d}$ & 1.5 & 3.5 & 6.3 & 2.4 & 3.4 \\
\hline
\end{tabular}

$\mathrm{E}_{\mathrm{o}}$ - evaporation from a free water surface $(\mathrm{mm}), \mathrm{k}$ - correction coefficients, $\mathrm{t}-$ mean monthly air temperature $\left({ }^{\circ} \mathrm{C}\right), \mathrm{ET}_{\mathrm{c}}-\mathrm{plant}$

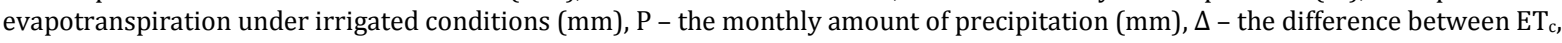
$\mathrm{P}(\mathrm{mm}), \mathrm{r}$ - pre-season readily available soil water reserve $(\mathrm{mm}), \mathrm{ET}_{\mathrm{a}}$ - plant evapotranspiration under non-irrigated conditions $(\mathrm{mm}), \mathrm{d}-\mathrm{a}$ deficit of readily available water in the soil $(\mathrm{mm}), \mathrm{s}$ - surplus water, i.e. water percolated into the soil layers below the active rhizosphere of plants ( $\mathrm{mm})$, Irr - water applied by irrigation (mm)

\section{Conclusions}

The comparison between $\mathrm{ET}_{\mathrm{o}}$ and Eo methods, which are commonly used for irrigation programs and crop evapotranspiration prediction, showed that differences in crop yield and irrigation water use efficiency were not statistically different. That indicates that both methods could be recommended for irrigation scheduling programs for pepper under the climatic conditions of the Vojvodina region. However, priority should be given to the $\mathrm{ET}_{\mathrm{o}} \mathrm{k}_{c}$ due to easy accessibility and reliability of data.

\section{Acknowledgment}

This research was supported by the Ministry of Education, Science and Technological Development of the Republic of Serbia, within the framework of a contract on the realization and financing of scientific research work in 2021 (project number 451-039/2021-14/200117).

\section{Declaration of competing interest}

The authors declare that they have no known competing financial interests or personal relationships that could have appeared to influence the work reported in this paper.

\section{References}

Allen, R.G., Pereira, L.S., Raes, D., Smith M. (1998). Crop evapotranspiration, Guidelines for computing crop water requirements. Irrigation and Drainage paper 56, FAO, Rome Italy, p. 300.

Antony, E., Singandhupe, R.B. (2004). Impact of drip and surface irrigation on growth, yield and WUE of capsicum (Capsicum annum L.). Agricultural Water Management $65,121-132$
Arya, C.K., Purohit, R.C., Dashora, L.K., Singh, P K., Mahesh, K. (2017). Estimation of irrigation water requirement of drip irrigated bell pepper (Capsicum annuum l. var. Grossum) in Jhalawar District of Rajasthan. Chemical Science Review and Letters, 6(21), 225-230.

Bos, M.G. (1985). Summary of ICID definitions of irrigation efficiency. ICID Bulletin, 34, 28-31.

Bošnjak, Dj. (1983). Evaporation from free water surface as a base for irrigation scheduling and its relationship to ETP of maize and soybean. Journal for Scientific Agricultural Research, 44(155), 323-344 (in Serbian).

Bošnjak, Dj. (2001). The problems of drought in the Vojvodina province and drought control measures. A Periodical of Scientific Research on Field and Vegetable Crops, 35, 391401 (in Serbian).

Bošnjak, Dj., Gvozdenović, Dj., Milić, S. (2005). Interval as a base for pepper scheduling. A Periodical of Scientific Research on Field and Vegetable Crops, 41, 113-118 (in Serbian).

Bryla, D.R., Thomas, J.T., Ayars, J.E. (2010). Weighing lysimeters for developing crop coefficients and efficient irrigation practices for vegetable crops. HortScience, 45(11), 1597-1604.

Delfine, S., Loreto, F., Centritto, M., Santarelli, G., Alvino, A. (2000). Effects of water stress on the yield and photosynthesis of field-grown sweet pepper (Capsicum annuum L). Acta Horticulture, 537, 223-229.

Demirel, K., Genç, L., Saçan, M. (2012). Effects of different irrigation levels on pepper (Capsicum annuum) yield and quality parameters in semi-arid conditions. Journal of Tekirdag Agricultural Faculty, 9(2), 7-15.

Dorji, K., Behboudian, M.H., Zegbe, J., Dominguez, A. (2005). Water relations, growth, yield, and fruit quality of hot pepper under deficit irrigation and partial rootzone drying. Scientia Horticulturae, 104, 137-149.

Echer, M.M., Fernandes, M.C.A., Ribeiro, R.L.D., Peracchi, A.L. (2002). Evaluation of Capsicum genotypes for resistance to the broad mite. Horticultura Brasileira, 20(2), 217221.

Ertek, A., Sensoy, S., Gedik, I., Kucukyumuk, C. (2007). Irrigation scheduling for green pepper grown in field conditions by using class-A pan evaporation values. American-Eurasian Journal of Agricultural \& Environmental Sciences, 2(4), 349-358. 
Ertek, A., Bolat, S. (2016). Growth and yield of pepper (Capsicum Annuum L.) under root zone restriction. Agricultural Research \& Technology, 2(5), 555-599.

FAOSTAT (2016). Faostat Database Search Results, http://www.fao.org Accessed May 21, 2020.

Ferrara, A., Lovelli, S., Di Tommaso, T., Perniola, M. (2011). Flowering, growth and fruit setting in greenhouse bell pepper under water stress. Journal of Agronomy, 10, 12 19.

Hargreaves G.H., Samani Z.A. (1985). Reference crop evapotranspiration from temperature. Applied Engineering in Agriculture, 1, 96-99.

Howell, A. (2001). Enhancing water use efficiency in irrigated agriculture. Agronomy Journal, 93, 281-289.

Kara, O.H., Yildirim, M. (2015). Water and radiation use efficiencies of pepper (Capsicum annuum L. cv. Carliston) Scholars Journal of Agriculture and Veterinary Sciences, 2(2A), 87-93.

Liu, H., Yang, H., Zheng, J., Dongdong Jia, D., Wang, J., Li, Y., Huang, G. (2012). Irrigation scheduling strategies based on soil matric potential on yield and fruit quality of mulched-drip irrigated chili pepper in Northwest China. Agricultural Water Management, 115, 232-241.

Molden, D., Oweis, T., Steduto, P., Bindraban, P., Hanjra, M.A., Kijne, J. (2010). Improving agricultural water productivity: between optimism and caution. Agricultural Water Management, 97, 528-535.

Padrón, R.A.R., Guedes, C.U.J., Swarowsky, A., Nogueira, U.C., Cerquera, R.R., Díaz-Pérez, C.J. (2015). Supplemental irrigation levels in bell pepper under shade mesh and in open-field: Crop coefficient, yield, fruit quality and water productivity. African Journal of Agricultural Research, 10(44), 4117-4125.

Pejić, B. (1993). A comparative study of soybean irrigation scheduling according to soil moisture and water balance. Zbornik radova Instituta za ratarstvo i povrtarstvo, 21, 145-157 (in Serbian).

Pejić, B. (2000). Evapotranspiration and morphological characteristics of corn depending on the depth of soil wetting and their relatioships with yield. Doctoral Thesis. Faculty of Agriculture Novi Sad (in Serbian).

Pejić, B., Maksimović, L., Milić, S. (2007). Effect of irrigation on yield of corn hybrids from different maturity groups. Zemljište i biljka, 56(2), 59-66 (in Serbian).

Pejić, B., Maheshwari, B.L., Šeremešić, S., Stričević, R., Pacureanu-Joita, M., Rajić, M., Ćupina, B. (2011a). Wateryield relations of maize (Zea mays L.) in temperate climatic conditions. Maydica, 56(4), 315-323.

Pejić, B., Gvozdanović-Varga, J., Milić, S., Ignjatović-Ćupina, A., Krstić, Dj., Ćupina B. (2011b). Effect of irrigation schedules on yield and water use of onion (Allium cepa L.). African Journal of Biotechnology, 10, 2644-2652.

Pejić, B., Mačkić, K., Pavković, S., Ljevnaić-Mašić, B., Aksić, M. Gvozdanović-Varga, J. (2016). Water-yield relations of drip irrigated watermelon in temperate climatic conditions. Contemporary Agriculture, 65(1-2), 53-59.

Pejić, B., Mačkić, K., Milić, S., Maksimović, L., Bajić, I., JančićTovjanin, M. (2018). Effect of surface and subsurface drip irrigation on yield and evapotranspiration of maize. Annals of Agronomy, 42(2), 1-8 (in Serbian).

Pejic, B., Mačkić, K., Koza, M. Jančić-Tovjanin, M., Gajić, B., Aksić, M. (2019). The effect of different irrigation scheduling regimes on tomato (Lycopersicon esculentum Mill.) yield under drip irrigation system. Annals of Agronomy, 43(1), 17-25 (in Serbian).

Republic Hydrometeorological Service of Serbia (2020), http://www.hidmet.gov.rs/ Accessed March 15, 2020.

Sahin, U., Kuslu, Y., Kiziloglu, F.M. (2015). Response of cucumbers to different irrigation regimes applied trough drip-irrigation system. The Journal of Animal and Plant Sciences, 25(1), 198-205.

Sezen, S.M., Yazar, A., Eker, S. (2006). Effect of drip irrigation regimes on yield and quality of field grown bell pepper. Agricultural Water Management, 81(1-2), 115-131.

Sezen, S.M., Yazar, A., Tekin, S., Eker, S., Kapur, B. (2011). Yield and quality response of drip-irrigated pepper under Mediterranean climatic conditions to various water regimes. African Journal of Biotechnology, 10(8), 13291339.

Showemimo F.A., Olarewaju J.D. (2007). Drought tolerance indices in sweet pepper (Capsicum annuum L.). International Journal of Plant Breeding and Genetics, 1, 29-33.

Smajstrla, A.G., Locascio, S.J., Weingartner, D.P., Hensel, D.R. (2000). Subsurface drip irrigation for water table control and potato production. Applied Engineering in Agriculture, 16, 225-229.

Stanhill, G. (1986). Water use efficiency. Advances in Agronomy, 39, 53-85.

Statistical Office of the Republic of Serbia (2019). https://publikacije.stat.gov.rs/G2018/Pdf/G20182051.p df Accessed March 20, 2020.

Tanaskovik, V., Chukaliev, O., Kanwar, S.R., Heng, L.K. Markoski, M., Spalevic, V. (2016). Nitrogen fertilizer use efficiency of pepper as affected by irrigation and fertilization regime. Notulae Botanicae Horti Agrobotanici Cluj-Napoca, 44(2), 525-532.

Tanner, C.B., Sinclair, T.R. (1983). Efficient water use in crop production: Research or Research. In: Taylor H.M. et al. (Ed.), Limitations to Efficient Water Use in Crop Production, ASA, Madison, WI, 1-27.

Thampi, P.S.S. (2004). A glimpse of the world trade in Capsicum. In: De A.K. (Eds.), Capsicum: the genus Capsicum, CRC Press Inc., Taylor and Francis Group, London, UK.

Trivikrama, J. R., Muralee K.G., Hema, H.V.K., Sumathi, P. (2018). Water requirement and deficit irrigation of capsicum crop using fixed irrigation intervals to crop stage under poly house. International Journal of Current Microbiology and Applied Sciences, 7(07), 2533-2538.

Viets, F.G. (1962). Fertilizers and the efficient use of water. Advances in Agronomy, 14, 223-264.

Vučić, N. (1976). Irrigation of agricultural crops. Faculty of Agriculture, Novi Sad, 439 p. (in Serbian).

Wang, Z., Zerihum, D., Feyen, J. (1996). General irrigation efficiency for field water management. Agricultural Water Management, 30, 123-132. 